\title{
THE INFLUENCE OF AMBIENT TEMPERATURE ON THE COURSE OF MYXOMATOSIS IN RABBITS
}

\author{
BY I. D. MARSHALL* \\ The Department of Microbiology, The John Curtin School of Medical Research, \\ Australian National University, Canberra, Australia
}

(With 2 Figures in the Text and Plate 12)

\section{INTRODUCTION}

Twenty years ago Thompson (1938) and Parker \& Thompson (1942) showed that rabbits held at ambient temperatures between $38^{\circ}$ and $40^{\circ} \mathrm{C}$. sometimes escaped infection or recovered after inoculation of an otherwise lethal dose of a highly virulent strain of myxoma virus.

During the last five or six years there have been repeated suggestions that myxomatosis spreading naturally through Australian wild rabbits was more lethal in winter than in summer. Although other climatic factors could not be excluded, Mykytowycz's (1956) observation that wild rabbits housed in unheated sheds and infected with an attenuated field strain of myxoma virus were more likely to die in winter than in the summer months reinforced the impression that environmental temperature could have a direct effect on the mortality rate in myxomatosis.

In earlier discussions of the changing case mortality rate in myxomatosis, attention was concentrated on the effects of the demonstrable alterations in the virulence of the virus and the genetic resistance of the host (Fenner, 1959). Possible effects of environmental temperature were then dismissed as unimportant, because under field conditions these would never approach the levels found necessary by Parker \& Thompson (1942) to allow rabbits to recover from infection with a highly virulent strain of myxoma virus. The present report shows that fluctuations in temperature comparable with those observed naturally in Australia have a profound effect upon the course of myxomatosis due to attenuated strains of virus, but no effect on the disease produced by the highly virulent strain.

\section{MATERIALS AND METHODS}

Virus strains. Two myxoma strains and one rabbit pox strain were used:

Myxoma strain Aust/Corowa/12-52/2A, a variant of Aust/Corowa/12-52/2 (KM 13) (Fenner \& Marshall, 1957) was used in all experiments. The mortality rate in adult susceptible rabbits inoculated with this strain and maintained under the usual laboratory conditions is approximately $60 \%$ compared to $90 \%$ for the original strain.

* Supported by a grant from the Wool Research Trust Fund. 
Brazil/Campinas/1949/1 (Lausanne), the highly virulent strain of myxoma virus used to initiate outbreaks of disease in Europe.

Rabbitpox (Utrecht), (Fenner, 1958).

Rabbits. Rabbits bred in the Animal Breeding Establishment of the Australian National University were used at the age of 4-6 months.

Gel diffusion tests. The Ouchterlony technique of plate gel diffusion as modified by Mansi (1957) was used for the detection of antibodies and soluble antigens in the sera of infected rabbits. Plates were incubated at room temperature overnight before reading.

Complement-fixation tests. The complement-fixation tests for the titration of haemolysin were carried out using the dropping pipette method of Donnelly (1951). The serial twofold dilutions of sera were incubated with washed sheep cells for $30 \mathrm{~min}$. in a $37^{\circ} \mathrm{C}$. water bath before adding $3 \mathrm{MHD}_{50}$ of complement to each tube. The tubes were shaken after $15 \mathrm{~min}$. incubation at $37^{\circ} \mathrm{C}$. and removed from the water bath after a further $15 \mathrm{~min}$. The titration end-point was taken at the point of $50 \%$ haemolysis after allowing the cells to settle.

Infectivity titrations. Both myxoma and rabbitpox viruses were titrated on the chorio-allantoic membranes of 11 - or 12-day-old chicken embryos. Readings were made 2 days later with rabbitpox and 3 days latter with myxoma virus.

Infection of experimental rabbits. Rabbits were inoculated intradermally at a shaved area of the right flank with an estimated $20-30 \mathrm{ID}_{50}$ of virus based on the pock count on the chorio-allantoic membrane (Fenner \& McIntyre, 1956).

Rectal and skin temperatures. A thermocouple of copper-constantan was used in conjunction with the circuit of a Cambridge slide-wire potentiometer* (Busse, 1944) to take skin and rectal temperatures. The system was calibrated against mercury thermometers in a water bath heated through steps of $5^{\circ} \mathrm{C}$. When taking the temperature of a rabbit, the circuit was held in balance for at least $5 \mathrm{sec}$. before the reading was taken.

\section{EXPERIMENTAL RESULTS}

\section{The effect of ambient temperature on the mortality rate in rabbits} infected with an attenuated strain of myxoma virus

The first experiment was designed solely to find whether the course of the disease due to an attenuated strain of myxoma virus could be altered by simulated summer or winter temperatures, including appropriate fluctuations between night and day at each level. The rabbits were acclimatized for 5 days before inoculation. Three groups of eighteen rabbits were held under the following conditions.

\section{Group 1. The cold room}

The rabbits were held in standard cages in a large ground level room with one wall open to the weather. The experiment was carried out during July 1958 and the minimum temperature recorded at the position of the group of cages was $-3^{\circ} \mathrm{C}$. (day 2 of the experiment). The temperature on 6 of the 33 nights was at or below

\footnotetext{
* Cambridge Instrument Co. Ltd., England.
} 
freezing-point. The day temperature rose to $27^{\circ} \mathrm{C}$. on one occasion, but usually the maximum was between $15^{\circ}$ and $20^{\circ} \mathrm{C}$., with 19 days within this range and 12 days below it.

Eighteen control rabbits which were convalescent from myxomatosis were housed under similar conditions.

\section{Group 2. The mild room}

The rabbits were held in a room of the experimental animal house with temperatures ranging from 20 to $22^{\circ} \mathrm{C}$. Specific controls were not included with this group. This is the environmental temperature used in previous experiments on the virulence of field strains of myxoma virus (Fenner \& Marshall, 1957).

\section{Group 3. The hot room}

The rabbits were held in a room of the experimental animal house with additional heating from four electric convection-type heaters. The heaters were turned on late each afternoon and off each morning. The maximum night temperature was $39^{\circ} \mathrm{C}$, and the night temperature never fell below $37^{\circ} \mathrm{C}$. The day temperatures usually fell to about $26^{\circ} \mathrm{C}$.

Eighteen control rabbits, which were convalescent from myxomatosis, were housed in this room.

Deaths not specifically due to myxomatosis were encountered in both the hot room and the mild room, but several attempts at isolating a causative organism failed. The most common symptoms were distention of blood vessels and haemorrhages, particularly in the walls of the large intestine, and a blood-stained discharge from the nostrils. In the hot room nine of the inoculated rabbits and five of the control rabbits died in this way between days 8 and 16 after the start of the experiment. Four of the inoculated rabbits in the mild room died with similar symptoms between days 5 and 12 , and a further six rabbits in other experiments in the animal house died at about the same time. These rabbits have been excluded from Table 1.

Despite the non-specific deaths the results are clear-cut: moderately high temperatures exert a sparing effect, and moderately low temperatures intensify the severity of the disease caused by the inoculation of an attenuated strain of myxoma virus. The results of two further experiments, which will be described later, are included in Table 1, and with the inclusion of these rabbits the death-rate in the mild room was $63 \%$ compared with $92 \%$ in the cold room and $30 \%$ in the hot room. As will be pointed out later, the last figure is inflated by the inclusion of several probably nonspecific deaths, and $10 \%$ might be a more correct figure.

The clinical picture presented by rabbits in the cold room differed greatly from that seen in the hot room. In the former the local lesion at the site of inoculation was soft and flat with diffuse edges. Swelling of the eylids progressed until they were usually completely closed by the 14th day after inoculation and there was a copious discharge from the eyes and the nose, with snuffling and eventually laboured breathing. There was also great swelling of the perineal region and the 
flat spreading secondary, tumours eventually became confluent over large areas of the head, ears, body and limbs (Pl. 12, fig. 1). Rabbits in the hot room, on the other hand, usually developed a fairly hard flat lump at the inoculation site, and this was strongly demarcated by the 10th day after inoculation. The lesion dried rapidly, usually with the formation of a crusty scab which sloughed by the end of the third or fourth week. Secondary tumours appeared as small, scattered, discrete nodules on ears, eyelids, nose, the perineal region, the body and occasionally the limbs. They quickly dried and scabbed. Often the rabbit never looked ill (Pl. 12, fig. 2).

Table 1. Mortality in groups of rabbits held at three different temperature ranges and infected with an attenuated strain of myxoma virus (Aust/Corowa/12-52/2 A)

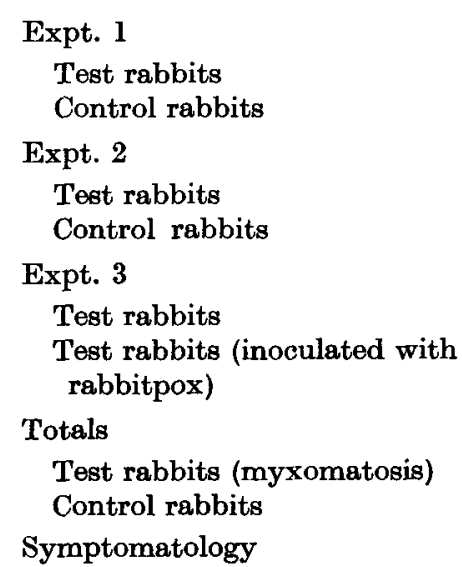

Expt. 1

$\begin{array}{ccc}\begin{array}{c}\text { Group 1, } \\ \text { cold room }\end{array} & \begin{array}{c}\text { Group 2, } \\ \text { mild room }\end{array} & \begin{array}{c}\text { Group 3, } \\ \text { hot room }\end{array} \\ \begin{array}{c}17 / 18^{*} \\ 0 / 18\end{array} & 10 / 14 & 1 / 9 \\ 16 / 18 & - & 0 / 13 \\ 0 / 18 & 10 / 18 & 7 / 18 \\ 3 / 3 & - & 0 / 18 \\ 2 / 3 & 2 / 3 & 1 / 3 \\ & 3 / 3 & 3 / 3 \\ 36 / 39(92 \%) & 22 / 35(63 \%) & 9 / 30(30 \%) \\ 0 / 36 & - & 0 / 31\end{array}$

* Numerator $=$ number of deaths; denominator $=$ number of rabbits in group.

In the mild room symptoms were rarely as extreme as those observed in the cold and hot rooms. However, as had been our experience with other attenuated strains tested in rabbits held in the mild room, there was a wide variation in symptomatology compared with the relative uniformity seen in the other two rooms.

The effect of ambient temperature on soluble serum antigens, circulating virus, antibody response, and body temperature in rabbits infected with myxomatosis

It has been shown that proliferation of myxoma virus in tissue cultures is greatly reduced at temperatures approaching $40^{\circ} \mathrm{C}$. (Thompson \& Coates, 1942), and this led to the view that the temperature effect seen in rabbits infected with myxomatosis was due to the change from optimum conditions for multiplication of the virus. If this were so, skin and rectal temperature readings in rabbits subjected either to fluctuating high or low temperatures might be expected to reach levels comparable to those required to affect the multiplication of the virus. A second 
experiment was carried out to test this hypothesis, and also to investigate aspects of the pathogenesis of the disease under the different ranges of ambient temperature.

The design of the experiment was similar to the first except that a thermostatically controlled cold room was used for the low-temperature group. The refrigeration unit was switched on late each afternoon and off in the morning, so that the rabbits were exposed to temperatures between $-1^{\circ}$ and $+1^{\circ} \mathrm{C}$. for $16 \mathrm{hr}$., and up to $15^{\circ} \mathrm{C}$. for $8 \mathrm{hr}$. each day.

Eighteen rabbits were again used in each group, and a similar number of myxomatosis-convalescent rabbits used as controls in the hot and cold rooms. In addition, groups of six rabbits in the hot and mild rooms were inoculated with the highly virulent Brazil/Campinas/1949/1 (Lausanne) strain of myxoma virus.

Skin and rectal temperatures of five rabbits in each group were taken with a thermocouple at the beginning and the end of each daily period of heat or cold. The skin temperatures were taken beneath unclipped fur on the flank opposite to that inoculated. At the same times samples of blood were collected and tested for virus titre, soluble antigen and specific antibody.

There was no consistent difference in the clinical response of rabbits inoculated with the Lausanne strain of myxoma virus and held in the mild and hot rooms. All died between days 9 and 13 .

Deaths in this experiment amongst rabbits inoculated with KM 13 virus are recorded in Table 1. Seven of the eighteen rabbits in the hot room died 13 days after inoculation during a period when the room temperature remained at $39-40^{\circ} \mathrm{C}$. for about $5 \mathrm{hr}$. The rabbits had not been exposed previously to this degree of stress, and this unintentional occurrence was due to inadequate heating control. The mean rectal temperature of five rabbits at the end of this period was $41.5^{\circ} \mathrm{C}$. and the, temperature of one rabbit ( $\mathrm{R} 206$ ), which died within half an hour of recording, was over $42^{\circ} \mathrm{C}$. All these rabbits showed early signs of recovery, and only antibodies could be detected in their post-mortem sera by the gel diffusion tests. However, they have been included in Table 1 as being deaths due to myxomatosis because these appeared to be suffering the most severe generalization of the disease in the rabbits in the hot room at that time, and also because no control rabbits died despite obvious signs of heat exhaustion. The room was not heated again during the experiment, and there were no further deaths in the group. The death-rates in groups 1 and 2 were comparable to those in the first experiment.

The different ranges of ambient temperatures had little effect on the daily means of body temperatures of the rabbits (Text-fig. 1) except during the period of overheating mentioned above. The daily mean skin temperatures in the cold room fluctuated widely, but were always considerably lower than in the mild or hot room during the periods of exposure to abnormal temperatures.

Virus (Text-fig. 2) appeared a day earlier in the blood of rabbits in the cold room than in the mild room, but there was little difference in the duration of viraemia or the maximum titre reached in the two groups. The rabbits in the hot room, however, showed a late and transient viraemia of low titre.

The serological findings are presented in Table 2 and they show striking differences between the rabbits held in the hot and cold rooms. All sera taken between 
day 4 and day 7 were negative and have been omitted from the table. Only soluble antigen was found in the sera of four of the five rabbits in the cold room, first appearing on day 9 or 10 and in two cases weakening in strength towards death. In the hot room soluble antigen did not reach a detectable level in the sera of any

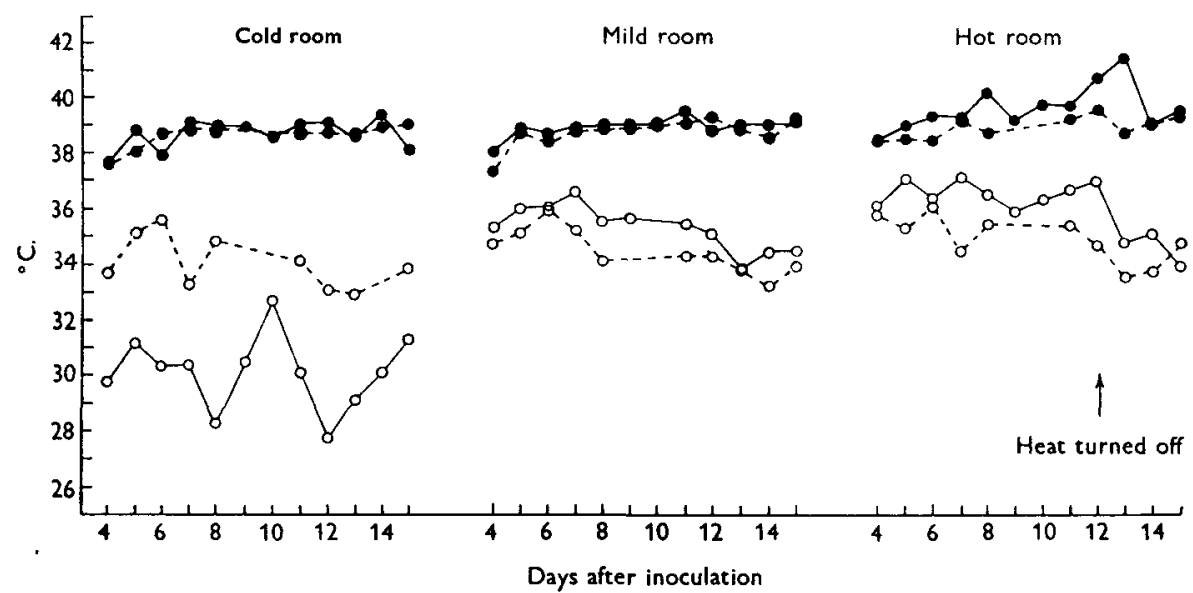

Text-fig. 1. Daily rectal and skin temperatures of rabbits held at three different ranges of ambient temperature. Each point represents the mean of either four or five rabbits. rectal temperature-morning; - - , rectal temperature-evening; $0-$, skin temperaturemorning, $\mathrm{O}--$, skin temperature evening.

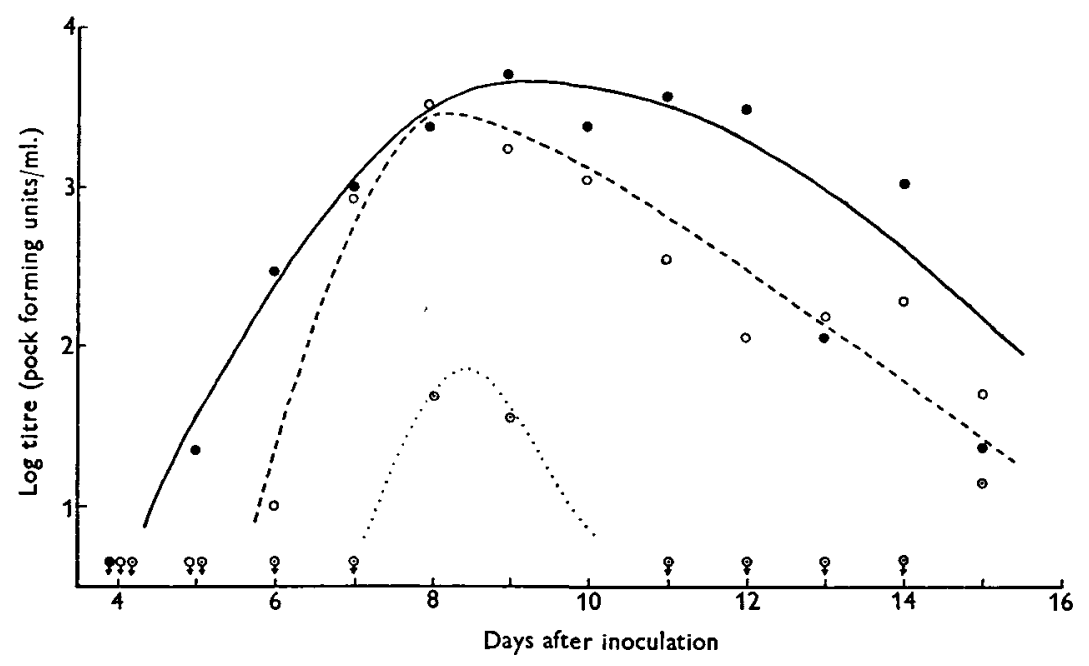

Text-fig. 2. Viraemia in whole blood of rabbits held at three different ranges of ambient temperature. Each point represents the mean of titres of either four or five rabbits. cold room; O--, mild room; $\odot--$, hot room.

of the rabbits at any time, and this includes rabbit number $\mathrm{R} 238$ which died 12 days after inoculation with the highly virulent Lausanne strain myxoma virus. On the other hand, antibodies appeared in all rabbits inoculated with KM 13 strain on day 11 or day 12, and were in relatively high concentration by day 13 or day 14 . In the mild room the sera of the two rabbits infected with KMI3 virus showed antibodies only, and these subsequently recovered. Of the other two, rabbit 


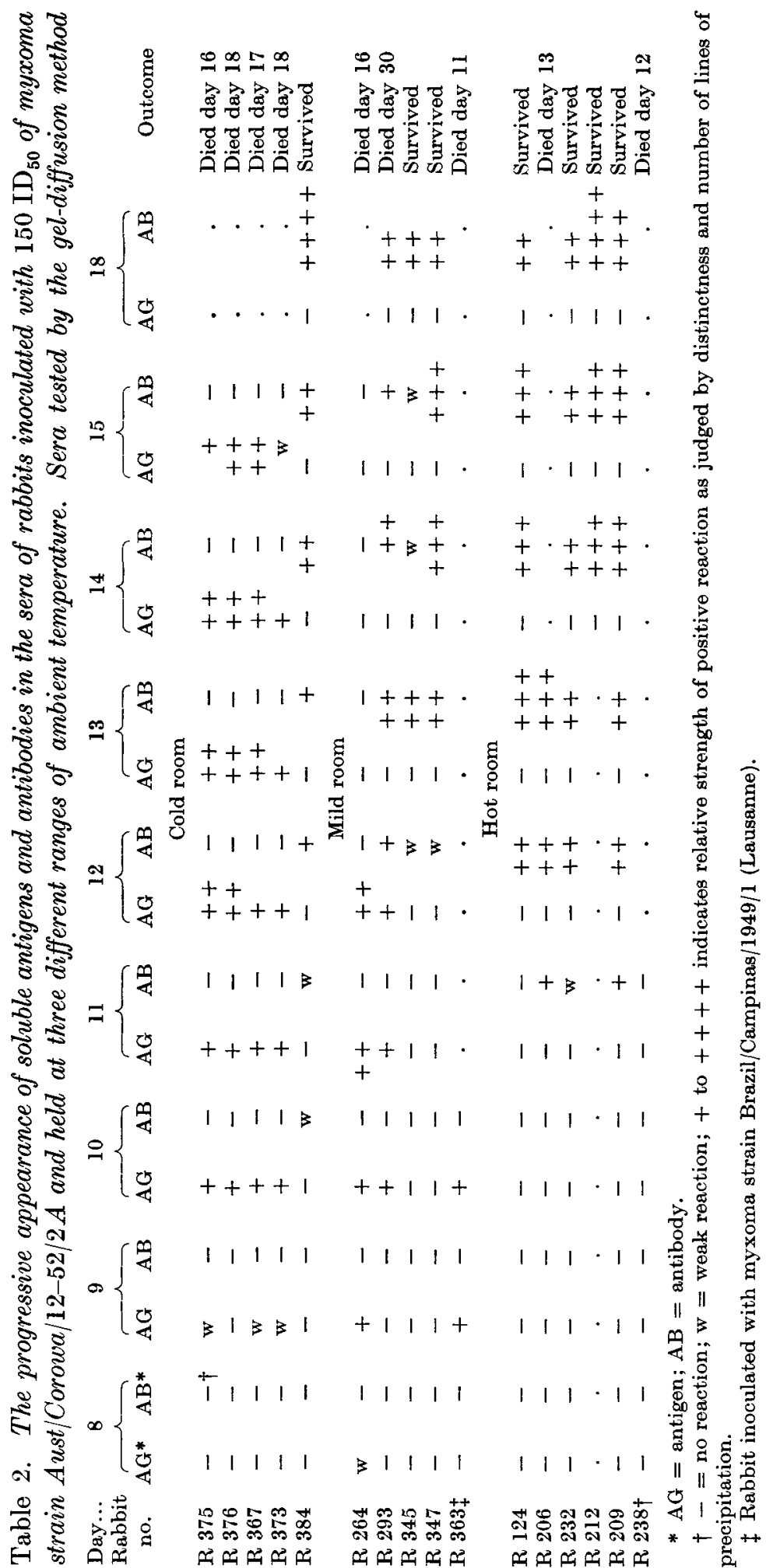


number R 264 suffered a severely progressive form of the disease culminating in death on day 16, and it had soluble antigen in its serum from day 8 to day 12 . Rabbit number $R 293$ had detectable antigen in its serum on days 10 and 11, both antigens and antibodies on day 12, and only antibodies on subsequent days. Although the symptoms in this rabbit were of the relatively mild nodular form, except for fairly severe involvement of the testes, scrotum and perineum, it died on day 30. The rabbit ( $R$ 263) in this group challenged with Lausanne virus died on day 11 and had detectable antigen present in its serum for the 2 days preceding death.

The fifth rabbit ( $R$ 384) in the cold room was the only one of the eighteen in that room to recover. Soluble antigen in the serum of this rabbit did not at any time reach a level detectable by the gel diffusion technique, and the weak antibody reaction seen on day 10 increased in strength until the last bleed on day 18 . By this time the lesions in the rabbit were strongly demarcated and it was well on the way to complete recovery. The skin and rectal temperatures did not differ significantly from the daily means of the other four rabbits in the group.

\section{The growth of myxoma and rabbitpox viruses on the chorio-allantoic membrane at various incubation temperatures}

Thompson \& Coates (1942) have shown that the growth of myxoma virus in tissue culture was much the same at $32^{\circ}, 35^{\circ}$ and $37^{\circ} \mathrm{C}$., but was greatly reduced at $40^{\circ} \mathrm{C}$. These experiments were repeated using the chicken embryo as host instead of tissue cultures.

Table 3. Yields of myxoma virus (KM 13 strain) and rabbitpox virus (Utrecht strain) grown on the chorio-allantoic membranes of developing chick embryos and incubated at various temperatures

\begin{tabular}{|c|c|c|c|c|c|c|c|}
\hline \multirow{3}{*}{$\begin{array}{c}\text { Temperature } \\
\text { of } \\
\text { incubation } \\
\left({ }^{\circ} \mathrm{C} .\right)\end{array}$} & \multicolumn{5}{|c|}{$\begin{array}{l}\text { Log virus titre } \\
\text { (pock forming units per ml.) }\end{array}$} & \multirow{2}{*}{\multicolumn{2}{|c|}{$\begin{array}{l}\text { Complement-fixing } \\
\text { antigen (myxoma) } \\
\text { Reciprocal of } \\
\text { serial twofold } \\
\text { dilution at } \\
50 \% \text { end-point }\end{array}$}} \\
\hline & \multicolumn{2}{|c|}{ Myxoma } & \multicolumn{3}{|c|}{ Rabbitpox } & & \\
\hline & Day 2 & Day 3 & Day 1 & Day 2 & Day 3 & Day 2 & Day 3 \\
\hline 32 & $6 \cdot 7$ & $7 \cdot 3$ & $7 \cdot 9$ & $8 \cdot 3$ & $8 \cdot 7$ & 512 & $>1024$ \\
\hline 35 & $6 \cdot 6$ & $6 \cdot 8$ & $7 \cdot 8$ & $8 \cdot 4$ & $8 \cdot 7$ & 512 & 768 \\
\hline 37 & $5 \cdot 9$ & $6 \cdot 2$ & - & 一 & - & 256 & 512 \\
\hline 39 & $1 \cdot 7$ & $<1 \cdot 0$ & $8 \cdot 1$ & $8 \cdot 3$ & Dead & 8 & 8 \\
\hline
\end{tabular}

The chorio-allantoic membranes of forty-eight 11-day-old chicken embryos were inoculated with large doses of KM13 strain myxoma virus and groups of twelve eggs incubated at $32^{\circ}, 35^{\circ}, 37^{\circ}$ and $39^{\circ} \mathrm{C}$. Six membranes from each group were reaped on each of the second and third days after inoculation, ground in a chilled mortar with measured amounts of alundum, frozen, ground again whilst thawing and suspended in $3 \mathrm{ml}$. of gelatine saline. The supernatants after centrifuging were titrated for virus content by chorio-allantoic inoculation and for soluble antigen by the complement-fixation test (Table 3). The yield of virus in eggs incubated at 
$37^{\circ} \mathrm{C}$. was slightly less than in those incubated at $32^{\circ}$ or $35^{\circ} \mathrm{C}$, and virus proliferation was almost completely inhibited at $39^{\circ} \mathrm{C}$., as was the production of soluble antigen.

Thompson \& Coates (1942) also found that the growth of vaccinia virus was less affected by high temperatures than that of myxoma virus. It was thought that a virus capable of growing at relatively high temperatures would be useful in elucidating the mechanism of the temperature effect seen in rabbits infected with myxomatosis, and rabbitpox virus was chosen as being a virus known to be highly lethal in rabbits held at mild temperatures.

Chorio-allantoic membranes were infected with rabbitpox virus in an experiment similar to that described above. The suspensions of ground membranes were tested only for virus content, with the results shown in Table 3. Membranes from embryos incubated at $39^{\circ} \mathrm{C}$. yielded just as much virus as those incubated at $32^{\circ}$ and $35^{\circ} \mathrm{C}$. A subsequent experiment suggested that growth of rabbitpox is prevented at $41^{\circ} \mathrm{C}$., although survival of embryos at this temperature was erratic.

\section{The effect of ambient temperature on the serological responses of rabbits inoculated with myxoma virus, rabbitpox virus, and washed sheep cells}

Groups of nine rabbits were held in a hot room, a mild room, and a cold room and three from each group inoculated with either myxoma virus (KM 13 strain), rabbitpox, or washed sheep cells. For this experiment a thermostatically controlled hot room was used. The temperature was held at $36-38^{\circ} \mathrm{C}$. for $16 \mathrm{hr}$. during each night, and allowed to drop to $28-30^{\circ} \mathrm{C}$. during the remaining $8 \mathrm{hr}$. The mild and cold rooms were adjusted as in the previous rabbit experiment.

Rabbits infected with myxoma virus received a dose of $150 \mathrm{ID}_{50}$ and those with rabbitpox a dose of 7 pock forming units (C.A.M.). Rabbits inoculated with sheep red cells received $2 \mathrm{ml}$. of $25 \%$ washed cells on day 0 , and further inoculations of $2 \mathrm{ml}$. of $50 \%$ cells on days 5 and 14 .

All rabbits were bled for serum every second or third day from day 5 to day 21 . Whole blood for virus assay was taken from rabbits infected with myxoma or rabbitpox on the same days.

The serological findings and levels of viraemia in rabbits infected with myxomatosis confirmed the findings of the earlier experiment (Table 2) and are therefore presented only in summary form in Table 4. In general, the rabbits in the cold room showed relatively high titres of circulating virus and soluble antigen, whilst two of the three in the hot room showed no soluble antigen and little or no circulating virus, but relatively early appearance of antibodies. However, the third rabbit (R 595), in the hot room had circulating virus on day 7 which subsequently rose to high titres, and soluble antigen appeared on day 17, 2 days before death. Temperatures of the rabbits were not taken daily, but two readings were made before the death of this rabbit on days 10 and 14. Skin and rectal readings on these occasions for rabbits $\mathrm{R} 595$, were, respectively, $34 \cdot 4^{\circ}-39 \cdot 1^{\circ} \mathrm{C}$. and $33 \cdot 6^{\circ}-38 \cdot 8^{\circ} \mathrm{C}$. compared with $34 \cdot 3^{\circ}-38 \cdot 5^{\circ}, 33 \cdot 8^{\circ}-38 \cdot 7^{\circ}$ and $34 \cdot 0-39 \cdot 1^{\circ}, 33 \cdot 5^{\circ}-39 \cdot 3^{\circ} \mathrm{C}$. for rabbits $R 596$ and $R 597$. It can be seen that the difference between the rabbits was not one of temperature regulation. 
Only one of the nine rabbits infected with rabbitpox recovered and this was one of the three in the cold room. However, the generalization of the disease in the rabbits in the cold room was far more extensive and the lesions at the site of inoculation larger and without the usual dark indurated centres seen at normal temperatures. The scrotum of the one buck in the cold room was grossly oedematous at death, a symptom not seen in the mild or hot rooms. The severity of these manifestations is reflected in the earlier appearance and higher titre of

Table 4. Viraemia and serological response in rabbits inoculated with myxoma virus strain Aust/Corowa/12-52/2 $A$ and rabbitpox (Utrecht) and held at three different ambient temperature ranges

\begin{tabular}{|c|c|c|c|c|c|c|c|c|}
\hline & \multicolumn{3}{|c|}{ Viraemia } & \multicolumn{2}{|c|}{ Soluble antigen } & \multicolumn{2}{|c|}{ Antibody } & \multirow[b]{3}{*}{ Outcome } \\
\hline & \multirow{2}{*}{$\begin{array}{c}\text { lst } \\
\text { appear- } \\
\text { ance } \\
\text { day }\end{array}$} & \multicolumn{2}{|c|}{ Maximum } & \multirow{2}{*}{$\begin{array}{c}\text { 1st } \\
\text { appear- } \\
\text { ance } \\
\text { day }\end{array}$} & \multirow{2}{*}{$\begin{array}{l}\text { Maximum } \\
\text { day }\end{array}$} & \multirow{2}{*}{$\begin{array}{c}\text { 1st } \\
\text { appear- } \\
\text { ance } \\
\text { day }\end{array}$} & \multirow{2}{*}{$\begin{array}{l}\text { Maximum } \\
\text { day }\end{array}$} & \\
\hline & & Day & Titre & & & & & \\
\hline Cold roon & & & & & fyxomatosis & & & \\
\hline R 556 & 10 & 10 & $3 \cdot 1$ & 10 & $10-14$ & - & 一 & Died day 21 \\
\hline R 557 & 7 & 14 & $4 \cdot 3$ & 10 & 14 & - & - & Died day 17 \\
\hline R 562 & 10 & 12 & $3 \cdot 8$ & 10 & $10-14$ & 17 & $17-19$ & Died day 19 \\
\hline \multicolumn{9}{|c|}{ Mild room } \\
\hline R 531 & 12 & 12 & $1 \cdot I$ & 17 & $17-21$ & 一 & - & $\begin{array}{l}\text { Survived protrac- } \\
\text { ted disease }\end{array}$ \\
\hline R 532 & 10 & 17 & $3 \cdot 9$ & 14 & $17-19$ & - & - & Died day 25 \\
\hline R 533 & 7 & 10 & $2 \cdot 5$ & 12 & 14 & 14 & $17-21$ & Died day 37 \\
\hline \multicolumn{9}{|l|}{ Hot room } \\
\hline R 595 & 7 & 12 & $3 \cdot 9$ & 17 & 19 & - & - & Died day 19 \\
\hline R 596 & - & - & - & - & - & 14 & $19-21$ & Survived \\
\hline R 597 & 12 & 12 & $1 \cdot 4$ & - & - & 14 & $19-21$ & Survived \\
\hline \multicolumn{4}{|c|}{ Cold room } & \multicolumn{3}{|c|}{ Rabbitpox } & & \\
\hline R 564 & - & - & - & - & - & 10 & $17-21$ & Survived \\
\hline R 577 & 7 & 7 & $4 \cdot 1$ & - & - & - & - & Died day 10 \\
\hline R 584 & 5 & 7 & $2 \cdot 3$ & - & - & 一 & - & Died day 9 \\
\hline \multicolumn{9}{|c|}{ Mild room } \\
\hline R 539 & 7 & 7 & 1.9 & - & - & - & - & Died day 8 \\
\hline R 542 & - & - & 一 & - & - & - & 一 & Died day 9 \\
\hline R 546 & - & - & - & - & - & - & - & Died day 10 \\
\hline \multicolumn{9}{|l|}{ Hot room } \\
\hline R 598 & 一 & - & - & 一 & - & - & - & Died day 10 \\
\hline R 599 & 7 & 7 & $1 \cdot 4$ & - & - & - & - & Died day 10 \\
\hline R 601 & - & - & - & - & - & - & - & Died day 9 \\
\hline
\end{tabular}

circulating virus when compared with the rabbits in the other rooms (Table 4). Soluble antigens were not detected in the sera of any of these rabbits by the gel diffusion test. Antibodies were detected on day 10 in the serum of one rabbit which recovered and these increased in concentration until day 17.

The haemolysin titres in rabbits inoculated with washed sheep cells were scattered, but within the same range in the three rooms (Table 5). Haemolysin was present in the sera of all rabbits when first bled on day 5 , so it seems unlikely that there would be differences in the time of first response under the different conditions. Two of the three rabbits in the hot room died with symptoms typical 
of anaphylaxis within $5 \mathrm{~min}$. of their third inoculation on day 17. This was the only suggestion in this experiment that some aspect of the defence mechanism might be affected by ambient temperature.

\section{DISCUSSION}

The emergence of attenuated variants of myxoma virus in the field in Australia (Fenner \& Marshall, 1957) has led to the recognition of factors affecting the behaviour of the disease which have been obscured previously by the overwhelming lethality of the laboratory strains of myxoma virus. The increasing genetic resistance of wild rabbits exposed to the drastic selection of annual outbreaks of myxomatosis in Australia has already been described (Marshall \& Fenner, 1958), and from the experiments reported here it is clear that climatic factors will also

Table 5. Haemolysin in the sera of rabbits inoculated with washed sheep red cells and held at three different ranges of ambient temperature

\begin{tabular}{ccc} 
& \multicolumn{2}{c}{ Maximum } \\
Cold room & Day & Titre \\
R 585 & 10 & $15,370^{*}$ \\
R 588 & 10 & 10,240 \\
R 591 & 14 & 7,680 \\
Mild room & & \\
R 549 & $10-14$ & 7,680 \\
R 550 & 10 & 20,480 \\
R 554 & 17 & 3,480 \\
Hot room & & \\
R 603 & 12 & $20,480 \dagger$ \\
R 605 & 10 & $7,680 \dagger$ \\
R 615 & 14 & 10,240
\end{tabular}

* Reciprocal of dilution at end-point of $50 \%$ haemolysis.

† Rabbit died of anaphylactic shock at third inoculation, day 17.

affect the case mortality rate of rabbits infected with strains of virus of the type commonly found in Australia in recent years. Fluctuating temperature ranges comparable to those found seasonally in the field, which profoundly affect the disease due to an attenuated strain, do not appear to affect the overwhelming course of myxomatosis in laboratory rabbits infected with a highly virulent strain of virus. Thompson (1938) and Parker \& Thompson (1942) found that a sustained very high temperature does exert a sparing effect in these cases.

The effect of ambient temperature on the clinical course of the disease and on the mortality rate is unequivocal, but the mechanisms causing this effect are complex. The growth of myxoma virus on the chorio-allantoic membrane is almost completely inhibited at $39^{\circ} \mathrm{C}$. and this supports the contention that the effect of high temperature is due to inhibition of virus proliferation. The fact that rabbitpox virus grows well on the chorio-allantoic membrane at $39^{\circ} \mathrm{C}$, and that neither mortality rate nor survival time of rabbits infected with this virus is altered by 
ambient temperatures which greatly affect myxomatosis, lends further support to the hypothesis. Nevertheless, two of the three rabbits infected with rabbitpox and held in the cold room showed more severe clinical symptoms, and had a higher titre of circulating virus than rabbits held at higher temperatures, although their survival time was not affected. Only the disease produced by the less virulent of the two strains of myxoma virus was influenced by ambient temperatures, and therefore a more appropriate comparison might be made with a milder disease than rabbitpox.

At no time did the surface skin temperature rise to a level which would inhibit the multiplication of virus on chorio-allantoic membranes. The intradermal or subcutaneous temperatures might be crucial here, but on the other hand there is little doubt that at least some multiplication of virus occurs in the organs of rabbits during the usual course of the disease (Hurst, 1937; Fenner \& Woodroofe, 1953), although the normal body temperature is about $39^{\circ} \mathrm{C}$. It is possible that relatively high titres of circulating virus are required to initiate infection in organs and deeper tissues; Fenner \& Marshall (1957) found that KM 13 strain myxoma virus inoculated intravenously would rarely cause infection, although the small dose administered would invariably infect when inoculated intradermally or subcutaneously. When a similar dose was given intramuscularly a less severe form of disease was produced.

Serological investigations, titrations of circulating virus, and recording of skin and rectal temperatures were undertaken in an attempt to elucidate the role of the host. With minor exceptions soluble antigens were not detected in rabbits in the hot room, and viraemia was transient and of a low titre. Antibodies appeared early and rose high. In the cold room soluble antigens were usually detected at relatively high concentrations, circulating virus persisted for many days and rose to high titres. Antibodies were rarely detected before death. Rabbits in the mild room showed a varying response. In this group all rabbits which died had soluble antigens in their sera at some time during the course of the disease, and the appearance of a high level viraemia was also associated with subsequent death. Some of the rabbits which had a relatively low concentration of soluble antigen with subsequent replacement by antibodies recovered, whilst others died. Those with no soluble antigen at any stage and with slight or no viraemia invariably recovered. At mild temperatures, then, the host response is extremely variable, whereas at high or low temperatures the host response is relatively uniform. There were only two exceptions to the uniformity of response at high or low temperatures in the rabbits that were observed intensively. One rabbit ( $\mathrm{R} 384$, Table 2 ) reacted clinically, serologically and pathologically as if it were in the hot room, and one rabbit ( $R$ 595, Table 4) in the hot room reacted as though it were in the cold room. The skin and rectal temperatures of these two rabbits did not differ significantly from the daily means of their room-mates and these exceptions cannot be explained on the basis that temperature influences only the multiplication of virus.

The results of the serological investigations suggest that the defence mechanism of the rabbit infected with myxomatosis might be enhanced by high and inhibited by low temperatures. Antibody production per se is apparently not altered by 
these conditions, for rabbits inoculated with washed sheep cells and held under three different ranges of temperature showed no difference in their titres of haemolysin (Table 5). The only hint in this experiment that some aspect of the defence mechanism might be affected was that two of the three rabbits in the hot room died of anaphylactic shock within $5 \mathrm{~min}$. of the third inoculation of sheep cells. Of course, this is an entirely different type of antigen from those encountered in viral diseases, but it will be remembered that Ipsen found that mice held at environmental temperatures of $6^{\circ}, 25^{\circ}$ and $35^{\circ} \mathrm{C}$. varied both in their immune response to tetanus toxoid and their resistance to tetanus toxin. Compared with $25^{\circ} \mathrm{C}$. low temperatures diminished and high temperatures increased the immune response to the toxoid (Ipsen, 1952). The survival times after challenge of nonimmune mice with tetanus toxin, on the other hand, were prolonged at low and shortened at high temperatures (Ipsen, 1951). Walker \& Boring (1958) found that the influence of temperature on mice infected with Coxsackie virus is in many ways similar to that on rabbits infected with myxomatosis, but they found no evidence that the defence mechanism is involved in the phenomenon. Fluctuating high temperatures failed to enhance the resistance of rabbits to rabbitpox. These observations suggest that the defence mechanism is not greatly influenced by ambient temperature, but further investigations with other systems are required. Possibly the defence mechanism can usually cope with myxoma virus proliferating at high temperatures, whereas it is overwhelmed by the invasiveness of the virus proliferating under optimum conditions.

No attempt was made to determine the shortest exposure to high temperature required to influence the outcome of myxomatosis, but the fact that in the second experiment no rabbits died in the hot room after the heat had been turned off on the 13th day suggests that a relatively short exposure during the early stages of infection was effective. The same experiment serves to emphasize that rabbits, and particularly sick rabbits, cannot tolerate an ambient temperature much above that of their body for extended periods of time. This will probably influence the performance of the disease in the field, for sick rabbits on the surface in open country are commonly exposed to considerably higher temperatures than were used in these experiments. Deaths due in part to heat exhaustion might thus obscure the sparing effect of moderately high ambient temperatures.

It is reasonable to suppose that midwinter epizootics would usually be associated with a high case-mortality rate, even though the virus strains appeared to be attenuated when tested under the usual animal room conditions.

\section{SUMMARY}

Ambient temperature profoundly affects the mortality rate and symptomatology in rabbits infected with an attenuated strain of myxoma virus. Simulated summer temperatures allowed at least $70 \%$ of infected rabbits to recover, whereas only $8 \%$ recovered when held at simulated winter temperatures. Similar fluctuating high temperatures did not reduce the lethality of rabbitpox or of a highly virulent strain of myxoma virus. 


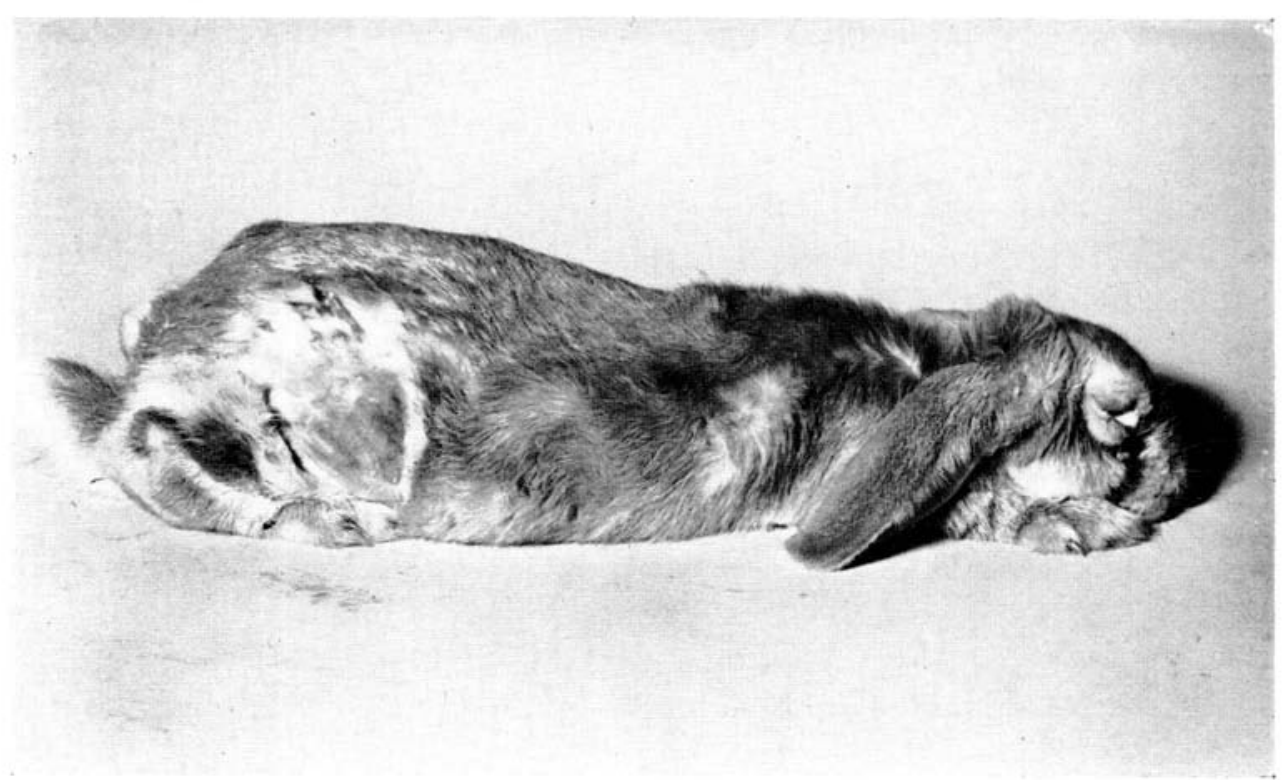

Fig. 1

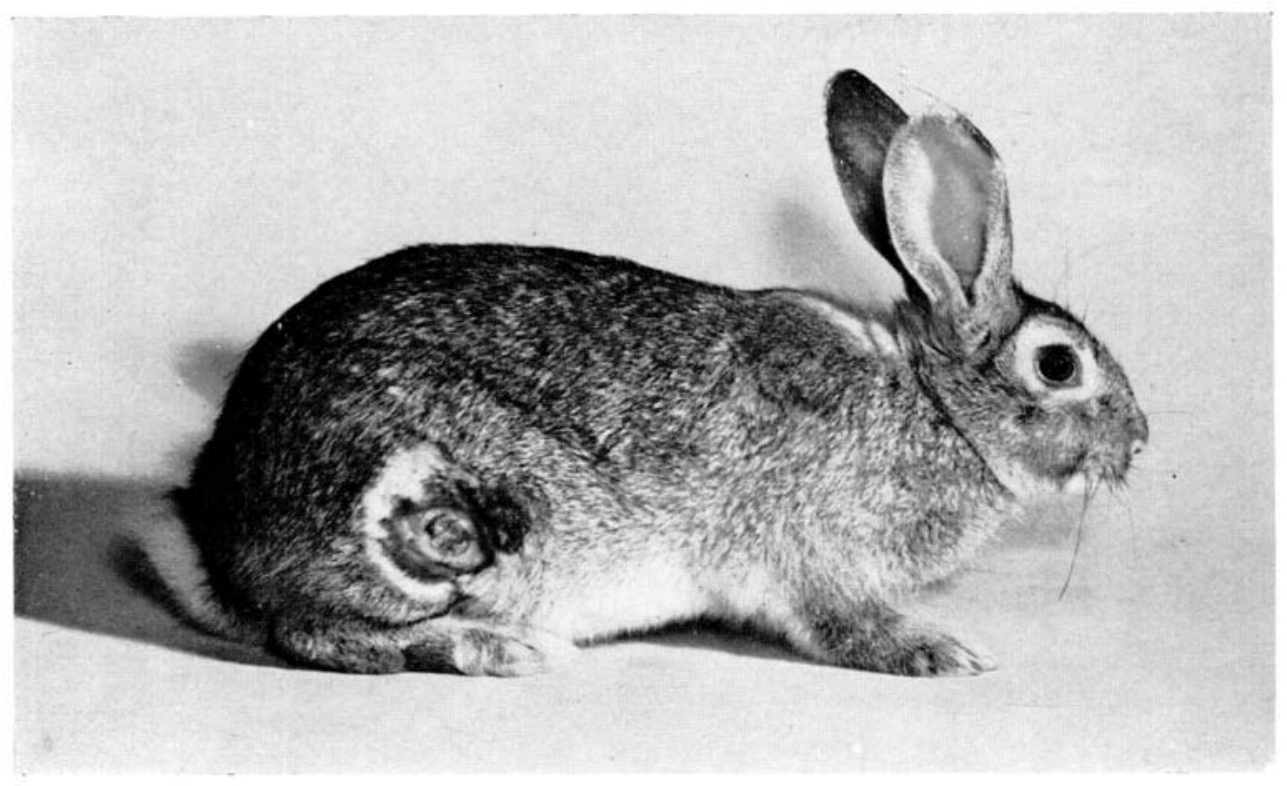

Fig. 2 
On the chorio-allantoic membrane of developing chicken embryos the proliferation of myxoma virus was almost completely inhibited at $39^{\circ} \mathrm{C}$., but the yield of rabbitpox virus was not reduced at this temperature.

The serological response and viraemia in rabbits held under different conditions of ambient temperature were investigated. Low temperatures resulted in high titres of circulating virus and soluble antigens, whereas at high temperatures antibody appeared early. Haemolysin production was not affected by ambient temperature.

The widely variable response of rabbits infected with the attenuated strain of myxoma virus when held at mild temperatures indicates that there is a considerable variation in the innate resistance of the host to the invasion of the virus. This resistance is enhanced by high and reduced by low ambient temperatures, so that the host response is relatively uniform under these conditions. The precise nature of this innate resistance has not been elucidated.

Now that attenuated strains of virus are common and many rabbits exhibit enhanced genetic resistance, seasonal temperatures will have an important influence on the mortality rate in epizootics of myxomatosis.

It is a pleasure to acknowledge the skilled technical assistance of $\mathrm{Mr} \mathrm{A}$. Brand.

\section{REFERENCES}

Busse, J. (1944). Medical Physics, 1. Ed. O. Glasser. Chicago: The Year Book Publishers Inc. Donnelly, M. (1951). Aust. J. exp. Biol. med. Sci. 29, 137.

FENNER, F. (1958). Virology, 5, 502.

Fenner, F. (1959). Harvey Lectures, p. 25. New York: Academic Press.

Fenner, F. \& Marshall, I. D. (1957). J. Hyg., Camb., 55, 149.

Fenner, F. \& McIntyre, G. A. (1956). J. Hyg., Camb., 54, 246.

Fenner, F. \& Woodroofe, G. W. (1953). Brit. J. exp. Path. 34, 400.

HURst, E. W. (1937). Brit. J. exp. Path. $18,1$.

IPSEN, J. (1951). J. Immunol. 66, 687.

IPSEN, J. (1952). J. Immunol. 69, 273.

Mansi, W. (1957). J. comp. Path. 67, 297.

Marshall, I. D. \& Fenner, F. (1958). J. Hyg., Camb., 56, 288.

MykYTowycz, R. (1956). Aust. J. exp. Biol. med. Sci. 34, 121.

PARKer, R. F. \& Thompson, R. L. (1942). J. exp. Med. 75, 567.

Thompson, R. L. (1938). J. infest. Dis. 62, 307.

Thompson, R. L. \& Coates, M. S. (1942). J. infect. Dis. 71, 83.

W ALKer, D. L. \& Boring, W. D. (1958). J. Immunol. 80, 39.

\section{EXPLANATION OF PLATE}

Fig. 1. Rabbit infected with KM 13 myxoma virus and showing symptoms typical of those held in the cold room. Photographed 20 days after inoculation of $150 \mathrm{ID}_{50}$ of virus.

Fig. 2. Rabbit infected with KM 13 myxoma virus and showing symptoms typical of those held in the hot room. Photographed 20 days after inoculation of $150 \mathrm{ID}_{50}$ of virus. 